\title{
EFEKTIVITAS PERAN KOMUNIKATOR DALAM PEMBERDAYAAN MASYARAKAT PADA PROGRAM KEMITRAAN BINA LINGKUNGAN PTPN V DI PEKANBARU
}

\section{Effectiveness of Communicator's Role in Community Empowerment in PTPN V Environmental Development Partnership Program in pekanbaru}

\begin{abstract}
Anuar Rasyid
Jurusan ilmu Komunikasi fakultas Ilmu sosial dan Ilmu Politik Universitas Riau, Kampus Bina Widya Jl. H.R Subrantas KM 12,5 Telp 0761-63277 Pekanbaru-Indonesia 28293

*email koresponden: anuar.rasyid@lecturer.unri.ac.id

Received: 2019. Revised: $19^{\text {th }}$ September 2019. Accepted: $20^{\text {th }}$ April 2020

Abstrak

Tujuan penelitian ini adalah menganalisis efektivitas peran komunikator dalam pemberdayaan masyarakat pada Program Kemitraan Bina Lingkungan (PKBL) PTPN V di Pekanbaru. Mix Methode digunakan dalam menganalisis penelitian ini. Sampel diambil 100 orang dari 418 orang dilakukan secara simple random sampling. Wawancara mendalam dengan kepala PKBL PTPN V dan 10 orang masyarakat penerima PKBL Hasil penelitian menunjukkan bahwa secara keseluruhan efektivitas peran komunikator dalam pemberdayaan masyarakat pada PKBL PTPN V di Pekanbaru adalah baik atau efektif. Hasil pemberdayaan yang dicapai juga berada pada kategori baik. Hal ini membuktikan bahwa peran komunikator yang baik dapat menghasilkan pemberdayaan masyarakat yang baik. Komunikator Program Kemitraan Bina Lingkungan PTPN V telah berhasil memberdayakan masyarakat sasarannya.
\end{abstract}

Kata kunci: Efektivitas, komunikator, pemberdayaan masyarakat.

\section{Abstract}

The purpose of this study was to analyze the effectiveness of the role of communicators in community empowerment in the Community Development Partnership Program PTPN V in Pekanbaru. Mix Method is used in analyzing this research. Samples were taken 100 people from 418 people conducted by simple random sampling. In-depth interviews with the head of PKBL PTPN V and 10 PKBL beneficiaries The results of the study showed that the overall effectiveness of the role of the communicator in community empowerment in the PKBL PTPN V in Pekanbaru was good or effective. The results of empowerment achieved are also in the good category. This proves that the role of a good communicator can produce good community empowerment. Communicator of Community Development Partnership Program PTPN V has succeeded in empowering the target community.

Keywords: Effectiveness, communicator, community empowerment 


\section{PENDAHULUAN}

Pembangunan masyarakat merupakan amanat dari Undang-Undang Dasar 1945, oleh karena itu mesti menjadi fokus perhatian dan tanggung jawab semua pihak, baik pemerintah, dunia usaha (swasta dan koperasi), serta masyarakat. Korporasi atau perusahaan berkontribusi secara wajar di dalam pembangunan daerah sebagai implementasi tanggung-jawab sosialnya melalui Program Kemitraan Bina Lingkungan (PKBL). Program Kemitraan dan Bina Lingkungan (PKBL) yang sering dikenal sebagai tanggung jawab sosial perusahaan (PKBL), merupakan salah satu model dari pemberdayaan masyarakat. Peran dunia usaha cukup strategis melalui program PKBL membantu pemerintah dalam menggerakkan, bahkan mempercepat laju roda perekonomian daerah. Sehingga pada gilirannya akan memberikan kontribusi terhadap peningkatan indeks daya beli karena berkurangnya angka pengangguran (Suherman, 2006).

Pelaksanaan PKBL di Indonesia dipayungi oleh (Undang Undang no 40, 2007) Pasal 74 yaitu Undang-Undang tentang Perseroan Terbatas. Dalam Undang-Undang ini pada pasal 74 dinyatakan bahwa semua Perseroan Terbatas wajib hukumnya melaksanakan PKBL, sehingga tanggung sosial menjadi bagian dari rencana penganggaran perusahaan. Selanjutnya, (Peraturan Menteri Negara Badan Usaha Milik Negara (BUMN) )No: PER 05/MBU/2007 tanggal 27 April 2007 Pasal 9. Badan Usaha Milik Negara menyisihkan 1-2\% dari laba bersih untuk Program Kemitraan Bina Lingkungan. Pengertian Program Kemitraan dan Bina Lingkungan telah dituangkan dalam surat Keputusan Menteri Badan Usaha Milik Negara tentang Program Kemitraan Badan Usaha Milik Negara dengan usaha kecil dan program bina lingkungan Nomor: KEP236/MBU/2003 tanggal 17 Juni 2003 pada pasal 1 ayat 4 yakni: - Program Bina Lingkungan adalah program pemberdayaan kondisi sosial masyarakat oleh BUMN di wilayah usaha BUMN tersebut melalui pemanfaatan dana dari bagian laba BUMN Kota Pekanbaru merupakan salah satu dari beberapa kabupaten/kota yang berada di sekitar PTPN V. Kota pekanbaru merupakan wilayah yang paling dekat dengan kantor pusat PTPN V dari beberapa kabupaten/kota yang lain. Bidang Sektor yang dibantu lebih beragam diterima oleh masyarakat yang ada di Kota Pekanbaru dibandingkan kabupaten/kota yang lain.

Konsep berkaitan dengan komunikator Komunikator sering disebut pengirim, sumber, source, sender, atau encoder adalah seseorang atau sekelompok orang atau suatu organisasi/institusi yang mengambil inisiatif menyampaikan pesan (Effendy, 2003) (Wiryanto, 2005) (Cangara, 2013). Aristoteles menyebut karakter komunikator sebagai ethos yang terdiri dari pikiran baik (good sense), akhlak yang baik (good moral character) dan maksud yang baik (good will). Hovland dan weiss menyebut ethos ini credibility yang terdiri dari dua unsur, keahlian (expertise) dan dapat dipercaya (trustworthness). Sedikitnya ada tiga karakteristik komunikator yang perlu diperhatikan yaitu: 1. Kredibilitas (credibility); 2. Daya Tarik Sumber (attractiveness); 3. Kekuasaan (power) (Sendjaja, 2008) (Cangara, 2012). Berkaitan dengan komunikator (Hamidi, 2007) membaginya menjadi tiga, yaitu: ethos komunikator, kredibilitas komunikator, dan efektivitas komunikator.

Komunikator merupakan salah satu unsur komunikasi yang penting. Komunikator yang baik sangat penting dalam program-program pembangunan. Konsep berkaitan dengan komunikator seperti yang dijelaskan beberapa ahli dengan istilah pengirim, sumber, source, sender, atau encoder adalah seseorang atau sekelompok orang atau suatu organisasi/institusi yang mengambil inisiatif menyampaikan pesan (Effendy, 2003) (Wiryanto, 2005) (Mulyana, 2007) (Cangara, 2013). Aristoteles menyebut karakter komunikator sebagai ethos yang terdiri dari pikiran baik (good sense), akhlak yang baik (good moral character) dan maksud yang baik (good will). Hovland dan weiss 
menyebut ethos ini credibility yang terdiri dari dua unsur, keahlian (expertise) dan dapat dipercaya (trustworthness). Sedikitnya ada tiga karakteristik komunikator yang perlu diperhatikan yaitu: 1 . Kredibilitas (credibility); 2. Daya Tarik Sumber (attractiveness); 3. Kekuasaan (power) (Sendjaja, 2008). Berkaitan dengan komunikator (Hamidi, 2007) membaginya menjadi tiga, yaitu: ethos komunikator, kredibilitas komunikator, dan efektivitas komunikator. (Rasyid, Saleh, Cangara, \& Priatna, 2015a) (Rasyid, Saleh, Cangara, \& Priatna, 2015b) (Rasyid, 2017) (Rasyid \& Lubis, 2018) (Rasyid, 2019) (Nasution \& Rasyid, 2018) (Nasution \& Rasyid, 2019a) (Nasution \& Rasyid, 2019b). Salah satu program yang ada kaitannya dengan program pembangunan adalah komunikator pada Program Kemitraan Bina Lingkungan (PKBL). Komunikator yang efektif dan efisien dibutuhkan dalam PKBL untuk memberdayakan masyarakat. Kemampuan komunikator dalam menyampaikan pesan PKBL akan memberikan efek kepada masyarakat. Pemberdayaan masyarakat merupakan efek dalam unsur komunikasi.Penelitian ini akan mengaudit efektiktifitas peran komunikator dalam pemberdayaan masyarakat Program Kemitraan Bina Lingkungan PTPN V di Pekanbaru.

\section{METODE PENELITIAN}

Penelitian dilaksanakan di kawasan wilayah kerja PTPN V di Pekanbaru. Perseroan Terbatas Perkebunan Nasional (PTPN V) beralamat di Jl. Rambutan No. 43. Pekanbaru. Penelitian dilakukan pada masyarakat sekitar PTPN V yang menerima bantuan program kemitraan PKBL PTPN V di Pekanbaru. Penelitian dirancang menggunakan pendekatan mix methode, metode kuantitatif yang diperkuat dengan metode kualitatif.

Populasi penelitian adalah masyarakat yang menerima bantuan di Kota Pekanbaru pada Tahun 2015, 2016 2017, 2018 sebanyak 418 orang. Pengambilan sampel pada Penelitian dilakukan secara simple random sampling. Sampel diambil sebanyak 100 orang. Pengumpulan data dilakukan melalui dua tahapan yaitu: (1) Pengumpulan data primer yaitu menggunakan instrumen berupa kuesioner tertutup yang disebarkan kepada 100 orang responden; (2) Wawancara terstruktur dilakukan terhadap kepala bagian PKBL PTPN V Pekanbaru, dan 10 orang masyarakat yang menerima bantuan. Analisis data dilakukan dengan statistik deskriptif dan kualitatif model miles dan huberman. Analisis deskriptif dilakukan dengan menghitung rataan skor. Skor alternatif jawaban yang terbentuk dari teknik skala peringkat dengan menggunakan skala antara 4 hingga 1 yang menggambarkan posisi sangat efektif, efektif, agak efektif dan tidak efektif. Rentang skala dihitung dengan rumus sebagai berikut (Durianto, 2003)

$R s=R M$

Keterangan:

Rs $=$ Rentang skala

$\mathrm{R}=$ Bobot terbesar-bobot terkecil

$\mathrm{M}=$ Banyaknya kategori bobot

Skala yang digunakan adalah skala Likert, skala 4 hingga 1. Maka rentang penilaian adalah sebesar 0,75. Hal ini didapatkan dari hasil rumus sebagai berikut:

$R s=\frac{4-1}{4}=0,75$

Rentang skala tersebut kemudian digunakan kedalam rentang skala keputusan sebagai bahan pengembalian keputusan dari hasil analisis data tersebut seperti pada tabel berikut ini:

Model yang digunakan dalam menganalisa data kualitatif adalah model interaktif Huberman dan

Tabel 1. Rentang Skala

\begin{tabular}{lll}
\hline NO & Kriteria & Rentang Skala \\
\hline 1 & Tidak Efektif & $1,00-1,75$ \\
2 & Cukup Efektif & $1,76-2,50$ \\
3 & Efektif & $2,51-3,25$ \\
4 & Sangat Efektif & $3,26-4,00$ \\
\hline \multicolumn{2}{l}{ Sumber: (Durianto, et all, 2003) }
\end{tabular}

Miles. Model ini menyebutkan adanya sifat interaktif antara kolektif data atau pengumpulan data dengan analisis data. Analisis data yang dimaksud adalah reduksi data, penyajian data dan verifikasi atau 
penarikan Simpulan. Reduksi data adalah mengelola data dengan bentuk analisis yang manajamkan, menggolongkan dan mengarahkan. Dengan mengorganisir data maka dapat dengan mudah menyajikan atau memaparkan data-data yang diperlukan yang disampaikan dengan cara induktif dengan demikian dapat ditarik Simpulan/verifikasi dalam menganalisis data penelitian (Bungin, 2008; Silalahi, 2012).

\section{HASIL DAN PEMBAHASAN}

\section{Audit Komunikasi}

Dalam organisasi modern, sistem komunikasi telah dilihat sebagai suatu aspek yang sangat penting untuk meningkatkan produktivitas organisasi. Upaya-upaya di dalam meningkatkan organisasi tidak terlepas dari meningkatkan kelancaran informasi dalam di dalam organisasi. Informasi menjadi aspek generik yang setiap harus dikontrol, diperiksa kesehatannya, sehingga tidak menganggu aspek-aspek lainnya. Tindakan itu tidak terlepas dari usaha mengaudit informasi di dalam sistem komunikasi organisasi.

Audit komunikasi juga dilaksanakan untuk tujuan meninjau efektivitas komunikasi serta tingkat kepuasan komunikasi yang ada di berbagai tingkat kerja dalam organisasi. Fokus utama audit komunikasi adalah untuk mengevaluasi sistem komunikasi internal yang menekankan aspek-aspek berikut seperti penilaian kualitas informasi yang mengalir dalam organisasi, jalinan hubungan di berbagai tingkat anggota kerja, umpan balik kinerja, lingkungan komunikasi dan keterlibatan bawahan dalam proses membuat keputusan (Bungin, 2008).

Dalam proses berkomunikasi, penyaluran informasi yang tepat, mudah dipahami, berkecukupan, dan mudah diperoleh akan bertindak sebagai katalis untuk perubahan. Justru dengan itu penyaluran informasi yang efektif dalam proses berkomunikasi akan membantu dalam usaha pencapaian tujuan suatu organisasi. Dalam sebuah organisasi anggota kerjanya membutuhkan informasi untuk tujuan melaksanakan tugas. (Bungin, 2008) menyatakan jika anggota sebuah organisasi tidak memiliki informasi yang mereka butuhkan, mereka akan menjadi lebih tidak menentu dan mungkin menghasilkan outcome yang kurang bermutu. Selain itu, ketidakpastian juga dapat terjadi ketika anggota sebuah organisasi menerima terlalu banyak atau sedikit informasi yang memenuhi keinginan dan kebutuhan mereka.

Selain itu, jika pekerja kekurangan infomasi dalam proses berkomunikasi, mereka tentu tidak memperoleh cara untuk membuat rencana kemajuan dalam organisasi itu. Mereka mungkin tidak melihat dengan jelas akan peluang promosi dan dengan itu terus saja memutuskan melakukan suatu yang menghambat kemajuan organisasi. Sealiran dengan permasalahan ini adalah wajar untuk anggota sebuah organisasi terutama diperingkat supervisor bersedia bertukar informasi dengan anggota yang lain sebagaimana organisasi dilayani, apakah tujuannya dan bagaimana cara untuk mencapai tujuan yang telah dirumuskan bersama (Bungin, 2008).

\section{Komunikator}

Komunikator sering disebut pengirim, sumber, source, sender, atau encoder adalah seseorang atau sekelompok orang atau suatu organisasi/institusi yang mengambil inisiatif menyampaikan pesan (Effendy, 2003) (Wiryanto, 2005) (Mulyana, 2007) (Cangara, 2013). Aristoteles menyebut karakter komunikator sebagai ethos yang terdiri dari pikiran baik (good sense), akhlak yang baik (good moral character) dan maksud yang baik (good will). Hovland dan weiss menyebut ethos ini credibility yang terdiri dari dua unsur, keahlian (expertise) dan dapat dipercaya (trustworthness). Sedikitnya ada tiga karakteristik komunikator yang perlu diperhatikan yaitu: 1. Kredibilitas (credibility); 2. Daya Tarik Sumber (attractiveness); 3. Kekuasaan (power) (Sendjaja, 2008) (Cangara, 2012) Berkaitan dengan komunikator (Hamidi, 2007) membaginya menjadi 
tiga, yaitu: ethos komunikator, kredibilitas komunikator, dan efektivitas komunikator.

Berdasarkan data Tabel 1, diketahui bahwa secara umum tanggapan penerima bantuan terhadap komunikasi PKBL adalah pada kategori tinggi. Hal ini terlihat rataan total bernilai 3,16. Hasil respon dari penerima bantuan berkaitan dengan beberapa indikator tersebut terdapat pada data Tabel 2, sebagai berikut, tanggapan penerima bantuan terhadap indikator kredibilitas ada pada kategori tinggi, dengan nilai rataan sebesar 3,33. Hal ini didukung oleh pendapat salah seorang sampel PKBL PTPN V berinisial HDN mengatakan bahwa:

"..Pembicara menyampaikan ceramah dengan menarik lah, kadang-kadang ada canda-canda juga, nggak teganglah karena dia sering menyela-nyela pembicaraan dengan lelucon. Ceramahnya mudahlah dimengerti dan bahasanya juga kita ngerti. Suasananya nyaman, nggak terasa sudah jam dua. Kemudian kata-kata pembicara sangat mudah kami pahami. Metode pembicara ada macam-macam, kadang dia langsung melakukan tanya jawab, pemberian contoh. Pembicara juga menggunakan alat bantu dalam membantu menyampaikan ceramah, dia pake alat yang disinarkan ke dinding, jadi kami juga bisa baca, nggak hanya mendengar. Kalo pengetahuan pembicara sangat baguslah karena materinya sangat bagus. Pembicara menganjurkan menggunakan dana sebaik-baiknya, dia juga mengingatkan kalau kita berhasil bukan untuk dia tapi untuk kita sendiri. Kalau tentang pengalaman, dari cara penyampaiannya kayaknya dia itu pengusaha yang memang sudah pengalaman. Kalo penjelasan mengenai program kemitraan ini sangat baik dan pembicara sangat menguasai materi sekali. Pembicara menyampaikan ceramah dengan sangat baik lah. Pembicara juga orang punya pendidikan tinggi karena ada gelarnya..."

Hasil wawancara dengan berbagai responden masyarakat bahwa komunikator mempunyai karakteristik yang baik. Karakter komunikator sebagai ethos yang terdiri dari pikiran baik (good sense), akhlak yang baik (good moral character) dan maksud yang baik (good will) dimiliki olh komunikator TJSP PTPN V. Kemudian dari sisi

Tabel 2 Rataan skor penerima bantuan terhadap komunikator PKBL PTPN V

\begin{tabular}{ll}
\hline $\begin{array}{l}\text { Komunikator } \\
\text { PKBL }\end{array}$ & Rataan Skor* \\
\hline Kredibilitas & 3,33 \\
daya tarik sumber & 3,09 \\
Kekuasaan & 3,09 \\
Pikiran baik & 3,17 \\
Akhlak yang baik & 3,12 \\
Maksud yang baik & 3,14 \\
\hline Rataan Skor* & $\mathbf{3 , 1 6}$ \\
\hline
\end{tabular}

Keterangan:* Selang Skor: 1-1,75=Rendah/tidak efektif; 1,76-2,50=Sedang/ agak efektif ; 2,513,25=Tinggi/ efektif ; 3,26-4=Sangat tinggi/ Sangat efektif kredibilitas (credibility), Daya Tarik Sumber dan Kekuasaan (power) komunikator PKBL PTPN V juga memilikinya. Hal ini diperkuat dengan hasil wawancara dengan Kepala PKBL PTPN V berinisial ST, sebagai berikut:

"..Petugas yang memberikan pelatihan bergantiganti tuh, kemarin dari LAZNAS (Lembaga zakat nasional dari Jakarta, Alfamart, PT. Corporindo dari Yogyakarta. Mereka menawarkan diri. Biasa berganti-ganti petugasnya. Materi nya administrasi keuangan, sama pemasaran hasil usaha. Materi tetap, tapikan orangnya berganti juga. Wali kota firdaus MT pernah datang dalam acara ini sesekali lah, itu pun waktu baru-baru jadi walikota. Dia menyampaikan kata sambutan aja lah, soalnya kemarin saya lupa isinya. Biasanya kita minta utusan dari pemerintah kota, biasa yang datang dari Dinas koperasi dan UMKM."

Hasil riset yang dilakukan oleh (Madlock, 2008) tentang pengaruh kompetensi pengawas komunikator dan gaya kepemimpinan pada pekerjaan karyawan dan kepuasan komunikasi. Peserta 220 orang (116 laki-laki dan 104 perempuan) bekerja di berbagai perusahaan di Midwest. Hasil temuan diketahui bahwa kompetensi pengawas komunikator menyumbang sebesar $68 \%$ dari kepuasan komunikasi. 
Selanjutnya, (Situmeang, 2012) menganalisis komunikator PKBL Pertamina. Hasil penelitian diketahui bahwa kemampuan berkomunikasi yang dilakukan oleh pendamping program kegiatan bersifat komunikasi dua arah atau komunikasi yang interaktif sehingga tidak menimbulkan perbedaan makna yang dimaksud. Pendamping program kegiatan yang ditunjuk oleh Pertamina merupakan pendamping program dengan kompetensi yang sesuai dengan kebutuhan masyarakat sehingga mampu menggerakkan masyarakat yang didampinginya sesuai dengan yang diharapkan, dan mampu berkomunikasi secara baik.

\section{Pemberdayaan Masyarakat}

Pemberdayaan masyarakat merupakan Akibat/ efek/ pengaruh adalah hasil yang terjadi pada pihak penerima/ komunikan. Efek atau hasil akhir dari suatu komunikasi, merupakan sikap dan tingkah laku individu, sesuai atau tidak sesuai dengan yang diinginkan oleh komunikator. Jika sikap dan tingkah laku individu tersebut sesuai, maka komunikasi dapat dikatakan berhasil, demikian pula sebaliknya (Sendjaja, 2008) (Muhammad, 2008) (Cangara, 2012). Efek yang diinginkan dari PKBL adalah pemberdayaan masyarakat. Oleh karena itu, aspekaspek yang dijadikan tujuan PKBL untuk memberdayakan masyarakat perlu diperhatikan dengan baik.

Istilah pemberdayaan (empowerment) telah lahir semenjak pertengahan abad ke-17 dengan makna menanamkan kewenangan (to invest with authority) atau memberi kewenangan (authorize). Dalam pengertian umum, pemberdayaan berarti untuk memungkinkan (to enable) atau mengijinkan (to permit), atau mengajarkan kepada seseorang unuk belajar memimpin dirinya sendiri (leading the people to learn to lead themselves). Dari banyak batasan, ada yang memfokuskan kepada pemberdayaan individu, yang berarti suatu proses untuk meningkatkan kemampuan individu. Seseorang dikatakan telah empowered adalah ketika ia telah dapat memimpin dirinya sendiri (Syahyuti, 2006).
Pada abad ke-20, istilah pemberdayaan digunakan oleh aktivis Gerakan Black Panther dalam mobilisasi politik di USA pada 1960-an. Namun konsep ini seolah mengalami kemandegan ("dorman") selama dekade 1970-an, dan baru pada pertengahan dekade 1980-an gerakan kaum wanita mempopulerkan kembali konsep pemberdayaan sehingga saat ini istilah pemberdayaan telah masuk ke berbagai disiplin ilmu, baik pada tataran teori maupun praktek (Jahi, 2006).

Menurut (Ledwith, 2005) sejarah munculnya pemberdayaan diawali dari upaya pembangunan masyarakat yang terjadi di Nigeria antara tahun 1927 dan 1949 yang dikritik oleh Batten karena pembangunan tersebut dimanfaatkan untuk kepentingan dominasi kolonial (Inggris). Suatu gerakan ke arah suatu filosofi pembebasan mendorong suatu perubahan terhadap kesadaran jenis kelamin dan kelas yang mengumpulkan daya gerak yang berkembang pada abad 20. Pergerakan untuk perubahan tersebut diberdayakan oleh adanya pemusatan kebebasan ideal dalam masyarakat sebagai suatu prinsip dalam bertindak.

Pemberdayaan adalah konsep kunci dalam jantung pembangunan masyarakat radikal (Ledwith, 2005). Dalam prosesnya, berkembanglah teori dan praktik secara seimbang. Praktek radikal menjadi titik awal yang menjembatani antara pengetahuan dan kekuatan dan komitmen untuk membangun bentuk kehidupan masyarakat yang berusaha secara serius untuk mendapatkan demokrasi dan keadilan sosial.

(Suharto, 2005) menyatakan bahwa pemberdayaan menunjuk pada kemampuan orang, khususnya kelompok rentan dan lemah sehingga mereka memiliki kekuatan atau kemampuan dalam:

1. memenuhi kebutuhan dasarnya sehingga mereka memiliki kebebasan, dalam arti bukan saja bebas mengemukakan pendapat, melainkan bebas dari kelaparan, kebodohan, dan kesakitan;

2. menjangkau sumber-sumber produktif yang memungkinkan mereka dapat meningkatkan

Anuar Rasyid. 31 
pendapatannya dan memperoleh barangbarang dan jasa-jasa yang mereka perlukan; dan

3. berpartisipasi dalam proses pembangunan dan keputusan-keputusan yang mempengaruhi mereka.

Beberapa pakar mengemukakan batasan yang beragam, pemberdayaan ditinjau dari tujuan, proses, dan cara-cara pemberdayaan:

1. Pemberdayaan bertujuan untuk meningkatkan kekuatan orang-orang yang lemah (Ife 1995).

2. Pemberdayaan mengajarkan pada individu atau kelompok bagaimana bersaing dalam aturan-aturan atau hukum (Ife 2003).

Pemberdayaan sebagai proses merupakan serangkaian kegiatan untuk memperkuat keberdayaan kelompok lemah dalam masyarakat, termasuk individu-individu yang mengalami masalah kemiskinan. Sebagai tujuan, pemberdayaan menunjuk pada keadaan atau hasil yang ingin dicapai oleh sebuah perubahan sosial, yakni masyarakat yang berdaya, memiliki kekuatan atau memiliki pengetahuan dan kemampuan dalam memenuhi kebutuhan hidupnya baik yang bersifat fisik, ekonomi, maupun sosial (Suharto, 2005).

Saat ini, istilah "pemberdayaan" telah menjadi suatu kata yang bersifat plastis dan digunakan dalam berbagai konteks, sehingga dapat mengaburkan makna yang sebenarnya (Jahi, 2006). Menurut teori Ilmu Jiwa, manusia memiliki berbagai daya, yakni daya atau kekuatan berpikir, bersikap, dan bertindak. Daya-daya itulah yang harus ditumbuhkembangkan pada manusia dan kelompok manusia agar tingkat berdayanya optimal untuk mengubah diri dan lingkungannya. Pemberdayaan masyarakat pada hakekatnya adalah sama dengan pembangunan masyarakat.

Berdasarkan uraian di atas, maka pemberdayaan dapat diartikan sebagai upaya untuk membantu orang-orang, agar dapat menolong diri mereka sendiri, atau upaya untuk memimpin orang-orang, agar belajar memimpin diri mereka sendiri dalam menggapai tujuannya. Tujuan pemberdayaan masyarakat dapat dicapai, (Jahi, 2006) menyatakan diperlukan beberapa persyaratan berikut:

1. Kemandirian masyarakat lokal, otonomi dalam pembuatan keputusan pada tingkat desa, dan partisipasi langsung yang demokratis dalam proses pemerintahan melalui perwakilan. Hal ini menyiratkan bahwa masyarakat yang berdaya harus mempunyai kemandirian (bersifat mandiri), mampu membuat atau mengambil keputusan.

2. Adanya ruang bagi ekspresi budaya dan kesejahteraan spiritual dan experiential social learning. Masyarakat yang berdaya harus memiliki kebebasan berekspresi, termasuk ekspresi budaya yang dimilikinya tanpa adanya rasa khawatir terhadap pihak lain. Mereka mau dan mampu belajar dari pengalaman hidup bermasyarakat untuk memperbaiki sistem sosialnya.

3. Akses pada lahan dan sumber daya lain, pendidikan untuk perubahan, dan perumahan dan fasilitas kesehatan. Masyarakat yang berdaya memiliki akses pada lahan dan sumber daya lain untuk memenuhi kebutuhan hidupnya, akses pada pendidikan yang diperlukan untuk meningkatkan kapasitas berpikir; memiliki rumah yang layak untuk tinggal bersama keluarganya, serta memiliki akses pada pelayanan kesehatan yang memadai.

4. Akses pada pengetahuan dan keterampilan (internal maupun eksternal) untuk menjaga stok modal alami dan lingkungan secara berkesinambung. Pengetahuan dan keterampilan merupakan modal utama bagi seseorang atau sekelompok orang agar dapat berdaya dan mandiri.

5. Akses pada pelatihan keterampilan, teknikteknik pemecahan masalah, teknologi tepat guna dan informasi. Pengetahuan dan keterampilan tersebut dapat digunakan untuk mengatasi masalah yang mereka hadapi sehingga ia tidak tergantung pada pihak lain. 
6. Partisipasi dalam proses pembuatan keputusan oleh semua orang, terutama wanita dan pemuda. Keputusan yang diambil berdasarkan kesepakatan dan melibatkan semua elemen masyarakat akan menjamin terlaksananya program pemberdayaan yang ditrencanakan. masyarakat aktiflah. Ada atau nggak kan kita harus aktif itu. Saya kasih informasi supaya juga bisa lebih mandiri pada tetangga-tetangga. Penghasilan meningkat lah, untuk omset meningkat juga. Jelaslah kan pendapatan sudah meningkat tentu kesejahtraan juga. Kalau sekarang sudah bisa sewa

Tabel 3 Rataan skor tanggapan sampel terhadap pemberdayaan masyarakat pada PKBL PTPN V

\begin{tabular}{ll}
\hline Peubah/ Indikator & Rataan Skor* \\
\hline Memenuhi kebutuhan dasar & 3,25 \\
Berpartisipasi dalam proses pembangunan & 3,22 \\
Meningkatkan kekuatan & 2,97 \\
Memahami aturan-aturan & 3,18 \\
Kemandirian masyarakat lokal & 3,17 \\
Memiliki pengetahuan & 3,03 \\
Memiliki keterampilan & 3,19 \\
Memiliki sikap & 3,12 \\
Tindakan & 3,21 \\
\hline Rataan Pemberdayaan Masyarakat & 3,15 \\
\hline
\end{tabular}

Keterangan: * Selang Skor: 1-1,75=Rendah/tidak efektif; 1,76-2,51=Sedang/ agak efektif ; 2,523,25=Tinggi/ efektif ; 3,26-4=Sangat tinggi/ Sangat efektif

Berdasarkan data Tabel 3, diketahui bahwa total rataan skor tanggapan sampel terhadap peubah pemberdayaan masyarakat adalah pada kategori tinggi sebesar 3,15. Hal ini menandakan efek dari PKBL PTPN V yang dilaksanakan menjadikan masyarakat berdaya. Secara keseluruhan indikator pemberdayaan memenuhi kebutuhan dasar sebesar 3,25 , berpartisipasi alam proses pembangunan sebesar 3,22, meningkatkan kekuatan sebesar 2,97, memahami aturan-aturan sebesar 3,18, kemandirian masyarakat lokal sebesar 3,17, memiliki pengetahuan sebesar 3,03, memiliki keterampilan sebesar 3,19, memiliki sikap sebesar 3,12, dan tindakan sebesar 3,21. Hal ini menunjukkan bahwa melalui PKBL PTPN V berhasil memberdayakan masyarakat dengan baik. Hasil wawancara dengan salah seorang penerima bantuan berinisial YC pada

"..Alhamdulillah terpenuhilah kebutuhan makanan sehari-hari di rumah, kalau ada sisa penjualan ya dibelikan ke baju. Kalau untuk tempat tinggal dari penghasilan itu kita sisihkan juga lah sedikit-sedikit”. Kalau pembangunan iyalah dengan kita bayar pajakkan berpartisipasi juga itu. Kalau sosial rumah untuk tinggal dan satu rumah lagi untuk produksi. Kalau aturan dari perusahaan tentang ini saya tahu, kan kita dikasih tahu mereka. aturanaturan Negara berupa Undang-undang, keputusan mentri tentang PKBL, ada tapi saya lupa kemaren mereka juga sampaikan itu, Sangat besar sekali manfaat modal pinjaman lunak untuk meningkatkan usaha. Saya bertindak sendiri mengelola keuangan soalnya kan usaha kecil-kecilan saja. Ya mampulah kan secara nggak langsung kita disini juga mempekerjakan tetangga di lingkungan kita untuk bantu-bantu buat makanannya. dapat pengetahuan dalam mengembangkan usaha waktu seminar itu. Pengetahuan tentang cara pembayaran cicilan disampaikan mereka juga. Sikap pembicara/karyawan PTPN V yang menjelaskan program kemitraan bagus, mereka sopan ramah lagi, ya kayak kita bukan orang lain lah kayak saudara nya juga dia buat. Syarat-syarat peminjaman terpenuhi, baru mereka kasih pinjaman sama kita, kalau nggak memenuhi syarat mereka nggak kasikan pinjaman..."

(Situmeang, 2012) menyatakan bahwa penilaian terhadap kemampuan masyarakat di bidang ekonomi 
termasuk kategori baik, walaupun belum merata keberdayaan masyarakat di bidang ekonomi, hal ini disebabkan karena rendahnya pengetahuan yang dimiliki oleh masyarakat.

Pemberdayaan dapat dilihat dari perspektif teori pemberdayaan dan hasil pemberdayaan. Pencarian teori tentang proses pemberdayaan pada pemberdayaan diambil dari berbagai disiplin ilmu, seperti ilmu pengetahuan politik, psikologi manajemen, pekerjaan sosial dan kesejahteraan sosial, pendidikan, dan manajeman, tetapi hanya beberapa sumber yang berfokus pada proses pemberdayaan yang benar-benar ditemukan.

Dalam literatur tentang manajemen, pemberdayaan karyawan telah menjadi isu kritis dan secara umum dianggap sebagai salah satu istilah-istilah manajemen bisnis, penulis mengatakan perusahaan dapat menggunakan untuk menavigasi tuntutan dunia dari persaingan global (yaitu, dengan memberdayakan karyawan mereka) (Blanchard, Carlos, \& Randolph, 2001) (Terblanche, 2003). (Carson, Carson, Roe, Birkenmeier, \& Philips, 1999) melakukan penelitian tentang hubungan antara pemberdayaan karyawan dan sikap kerja; Namun, perhatian mereka tidak dengan jalan pemberdayaan, akan tetapi hubungan antara pemberdayaan dan komitmen organisasi terhadap hasil kerja. (Santosa \& Priyono, 2012) berpendapat bahwa pada setiap proses pemberdayaan dituntut penguatan masyarakat dalam peningkatan kapasitas, kemandirian dan kreativitas mengelola berbagai kegiatan produktif.

Berdasarkan perspektif hasil, pemberdayaan menurut para ahli antara lain: (Karsidi, 2003) menyebutkan beberapa aspek penting yang perlu mendapat perhatian dalam pemberdayaan masyarakat tani dan nelayan: (1) Pengembangan organisasi atau kelompok masyarakat yang dikembangkan dan berfungsi dalam mendinamisir kegiatan produktif masyarakat; (2) Pengembangan jaringan stategis antar kelompok atau organisasi masyarakat yang terbentuk dan berperan dalam pengembangan masyarakat tani dan nelayan; (3) Kemampuan kelompok tani dan nelayan dalam mengakses sumber-sumber luar yang dapat mendukung pengembangan mereka, baik dalam bidang informasi pasar, permodalan, serta teknologi dan manajemen, termasuk di dalamnya kemampuan lobi ekonomi. Hal ini lebih dikenal sebagai kemampuan memanfaatkan jaringan ekonomi; (4) Pengembangan kemampuan-kemampuan teknis dan manajerial kelompok masyarakat, sehingga berbagai masalah teknis dan organisasi dapat dipecahkan dengan baik. Dengan demikian pemberdayaan masyarakat memerlukan kelompok masyarakat yang memiliki dinamika, sehingga dapat membantu anggota dan kelompoknya untuk lebih mandiri.

Pemberdayaan juga melibatkan aspek kognitif, psikomotorik, psikologis, ekonomi dan politik (Jahi, 2006). Lebih lanjut, (Karsidi, 2003) menyatakan bahwa untuk mewujudkan kemandirian petani dan nelayan dapat ditempuh dengan berbagai upaya berikut: (a) memulai dengan tindakan mikro dan lokal; (b) pengembangan sektor ekonomi strategis sesuai dengan kondisi lokal (daerah); (c) mengganti pendekatan wilayah administratif dengan pendekatan kawasan; (d) membangunkembali kelembagaan masyarakat; (e) mengembangkan penguasaan teknis; (f) pengembangan kesadaran dan proses demokratisasi ekonomi; (g) membangun jaringan ekonomi strategis; dan (h) kebijakan pemerintah yang mendukung upaya pemberdayaan.

\section{KESIMPULAN}

Berdasarkan hasil pembahasan maka dapat disimpulkan bahwa peran komunikator dalam pemberdayaan masyarakat pada Program Kemitraan Bina Lingkungan PTPN V di Pekanbaru adalah efektif. Tanggapan responden terhadap peran komunikator adalah efektif. Hal ini menunjukkan bahwa responden menilai komunikator sudah berperan dengan baik. Berdasarkan hasil analisis dan wawancara terhadap responden terlihat pemberdayaan masyarakat sudah efektif.

\section{Daftar Pustaka}

Blanchard, K., Carlos, J. P., \& Randolph, A. (2001). The 3 Keys to Empowerment: Release The Power Within People for Astonishing Results. San Francisco: CA: Berrett-Koehler. 
Bungin, B. (2008). Analisa Data Penelitian Kualitatif. Jakarta: RajaGrafindo Persada.

Cangara. (2012). Pengantar Ilmu Komunikasi. Jakarta: Raja Grafindo Persada.

Cangara. (2013). Perencanaan dan Strategi Komunikasi. Jakarta: RajaGrafindo Persada.

Carson, K. D., Carson, P. P., Roe, C. W., Birkenmeier, B. J., \& Philips, J. S. (1999). Four commitment profiles and their relationship to empowerment, services recovery, and work attitudes. Public Personnel Management.

Durianto, e. a. (2003). Inovasi Pasar dengan Iklan Yang Efektif. Departemen Pendidikan. Jakarta: Gramedia Pustaka Umum.

Effendy, O. U. (2003). Komunikasi: Teori dan Praktek. Bandung: Remaja Rosdakarya.

Hamidi. (2007). Metode Penelitian dan Teori Komunikasi. Malang: UMM Press.

Jahi, A. (2006). Pemberdayaan: Dalam Teori dan Praktek. IPB, Program Mayor Ilmu Penyuluhan Pembangunan, Bogor.

Karsidi, R. (2003). Pemberdayaan Masyarakat Petani dan Nelayan Kecil. Dalam Membentuk Pola Perilaku Manusia Pembangunan. (I. Y. Sudradjat., Penyunt.) Bogor: IPB Press.

Ledwith, M. (2005). Community Development: A Critical Approach. Bristol.UK: The Policy Press University of Bristol.

Madlock, P. e. (2008). The link between leadership style, communicator competence, and employee satisfaction. International Journal of Business Communication, 45(1), 61-71.

Muhammad, A. (2008). Komunikasi Organisasi. Jakarta: Bumi Aksara.

Mulyana, D. (2007). Ilmu Komunikasi Suatu Pengantar. Bandung: Remaja Rosdakarya.

Nasution \& Rasyid. (2019b). Komunikasi sosial Pembangunan. Pekanbaru: Taman karya.

Nasution, B., \& Rasyid, A. (2018). Implementation Of CSR Communication In Community Empowerment at PT. Energi Mega Persada. International Journal of Research In Social Sciences, Vol. 27. No.1. .

Nasution, B., \& Rasyid, A. (2019a). Analyzing Communication Between Government and Community In The Flow Of Cross-Border Goods In The Regency of Meranti Island. International Journal of Research In Social Sciences., Vol. 31. No.1.

Peraturan Menteri Negara Badan Usaha Milik Negara (BUMN) . (t.thn.). Peraturan Menteri Negara Badan Usaha Milik Negara (BUMN) No: PER 05/MBU/2007 tanggal 27 April 2007 Pasal 9.

Rasyid. (2019). Komunikasi CSR dalam Pemberdayaan Masyarakat. Pekanbaru: Taman karya.

Rasyid, A., \& Lubis, E. E. (2018). Correlation Among Communication Noise Corporate Social Responsibility
Program With Community Empowerment And PTPN $\mathrm{V}$ Image In Pekanbaru. International Journal of Research In Social Sciences, Vol. 20 No. 1.

Rasyid, A., Saleh, A., Cangara, H., \& Priatna, W. B. (2015a). The Role Of Communication In Corporate Social Responsibility. International Journal of Research In Social Sciences, Vol. 5, No.7.

Rasyid, Anuar. (2017). Komunikasi Program Tanggung Jawab Sosial Perusahaan dalam Pemberdayaan Masyarakat untuk Membangun Citra dan Reputasi PTPN $V$ di Pekanbaru. Disertasi, Institut Pertanian Bogor, Bogor.

Rasyid, Saleh, Cangara, \& Priatna. (2015b). Komunikasi Dalam Corporate Social Responsibility Perusahaan : Pemberdayaan Masyarakat Dan Membangun Citra Positif. Mimbar, Vol. 31, No. 2. .

Santosa, I., \& Priyono, R. E. (2012). Diseminasi model pemberdayaan masyarakat desa melalui pengelolaan agrowisata. Mimbar., 28(2), 181-190.

Sendjaja, S. D. (2008). Pengantar Ilmu Komunikasi. Jakarta: Universitas Terbuka.

Silalahi, U. ( 2012). Metode Penelitian Sosial. Bandung: Refika Aditama.

Situmeang, I. (2012). Komunikasi organisasi melalui kegiatan tanggung jawab sosial perusahaan (Kasus PT Pertamina Refinery Unit VI Balongan). disertasi, Institut Pertanian Bogor, Bogor.

Suharto, E. (2005). Membangun Masyarakat Memberdayakan Masyarakat: Kajian Strategis Pembangunan Kesejahteraan Sosial \& Pekerjaan Sosia. Bandung: Refika Aditama.

Suherman, M. (2006). Peranan corporate sosial responsibility (CSR) dalam menurunkan angka kemiskinan di Jawa Barat. Jurnal Mimbar, 22(3), 317332.

Syahyuti. (2006). 30 Konsep Penting dalam Pembangunan Pedesaan dan Pertanian. Jakarta: Bina Rena Pariwara.

Terblanche, F. (2003). Empowering people in organization. Mousaion, 21(2), 128-137.

Undang Undang no 40. (2007). Undang-Undang No.40 tahun 2007 Pasal 74 yaitu Undang-Undang tentang Perseroan Terbatas.

Wiryanto. (2005). Pengantar Ilmu Komunikasi. Cetakan Keempat. Jakarta: Grasindo. 